\title{
Ukuran Perusahaan, Komite Audit, Opini Audit, Ukuran KAP dan Audit Delay di Perusahaan Transportasi
}

\author{
Arie Pratania Putri1 \\ Fakultas Ekonomi \\ Universitas Prima, Indonesia \\ Yosevin Yovenia ${ }^{3}$ \\ Fakultas Ekonomi \\ Universitas Prima, Indonesia
}

\author{
Ricky Utomo² \\ Fakultas Ekonomi \\ Universitas Prima, Indonesia \\ Ayu Cindi Novika 4 \\ Fakultas Ekonomi \\ Universitas Prima, Indonesia
}

\begin{abstract}
Surel : rickyry12@gmail.com
ABSTRAK

Penelitian ini bertujuan untuk menganalisis pengaruh Ukuran Perusahaan, Komite Audit, Opini Audit Dan Ukuran KAP terhadap Audit Delay pada Perusahaan Transportasi di Indonesia Metode kuantitatif digunakan pada analisa penelitian ini. Digunakannya teknik purposive sampling menyisakan 28 perusahaan dari 46 populasi perusahaan, sehingga total sampel pada analisis ini adalah sebanyak 84 sampel data. Dengan adanya variabel dummy pada variabel terikat (Audit Delay) maka digunakan regresi logistik dalam proses penelitiannya. Hasil penelitian adalah secara parsial variabel bebas yang berpengaruh adalah Opini Audit sementara Ukuran Perusahaan, Komite Audit, dan Ukuran KAP tidak berpengaruh. Secara simultan, seluruh variabel independen berpengaruh secara keseluruhan terhadap variabel dependen dengan tingkat signifikansi sebesar 0,000 .
\end{abstract}

Kata Kunci: Ukuran Perusahaan; Komite Audit; Opini Audit; Ukuran KAP; Audit Delay.

\section{Company Size, Audit Committee, Audit Opinion, KAP Size and Audit Delay in Transportation Companies}

\section{ABSTRACT}

The purpose of the study is to analyze the effect of the Size of Company, Audit Committee, Audit Opinion and the Size of Public Accountant Firm on Audit Delay in Transportation Companies in Indonesia. Quantitative methods are used in the analysis of this study. The use of purposive sampling technique leaves 28 companies from 46 populations companies, so that the total of samples in this analysis are 84 data. As the dependent variable (Audit Delay) is dummy variable, logistic regression is used in the research process. The result of this study is that partially the independent variable that has an effect is the Audit Opinion while the Size of Company, the audit committee, and the Size of Public Accountant Firm have no effect. Simultaneously, all independent variables have an overall effect on the dependent variable with a significance level of 0.000 .

Keywords: $\quad$ Company Size; Audit Committee; Audit Opinion; KAP size; Delay Audits.

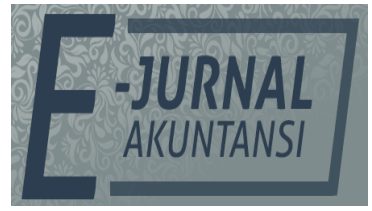

e-ISSN 2302-8556

Vol. 31 No. 6

Denpasar, Juni 2021

Hal. 1401-1412

DOI:

10.24843/EJA.2021.v31.i06.p04

PENGUTIPAN:

Putri, A.P., Utomo, R., Yovenia, Y., \& Novika, A.C. (2021). Ukuran Perusahaan, Komite Audit, Opini Audit,

Ukuran KAP dan Audit

Delay di Perusahaan

Transportasi. E-Jurnal Akuntansi, 31(6), 1401-1412

RIWAYAT ARTIKEL: Artikel Masuk: 23 Maret 2021 Artikel Diterima: 25 Mei 2021

Artikel dapat diakses : https://ojs.unud.ac.id/index.php/Akuntansi/index 


\section{PENDAHULUAN}

Laporan keuangan adalah suatu sumber informasi yang dapat menggambarkan kinerja perusahaan dalam periode tertentu yang berguna bagi pihak manajemen, pemegang saham, kreditur maupun masyarakat. Laporan keuangan yang dipublikasikan perusahaan harus mempunyai suatu kredibilitas dan dapat dipertanggungjawabkan. Kebenaran suatu laporan keuangan dapat dianalisa dan diverifikasi oleh jasa akuntan publik yang independen. Selain independen, akuntan publik juga perlu memiliki sikap profesional yang dapat ditunjukkan dari Audit Delay.

Audit Delay merupakan kemampuan auditor dalam melakukan penyelesaian laporan audit dengan tepat waktu terhitung dari hari akhir tahun buku hingga hari terbit laporan. Semakin baik dan berkualitas seorang auditor, semakin kecil kemungkinan terjadi Audit Delay. Hal - hal yang dapat mempengaruhinya berupa ukuran perusahaan, komite audit, opini audit, dan ukuran KAP.

Ukuran perusahaan adalah tolak ukur skala perusahaan berdasarkan jumlah aktiva yang perusahaan miliki. Audit Delay jarang dialami oleh perusahaan besar dikarenakan perusahaan memiliki aset yang banyak sehingga auditor lebih mudah dan cepat dalam melakukan pemeriksaan audit. Perusahaan besar juga cenderung mendesak ketepatan waktu auditor untuk disampaikan kepada pengguna laporan keuangan.

Ningsaptiti (2010) dalam (Puspitasari \& Latrini, 2014) menjelaskan bahwa ukuran perusahaan dapat menyatakan barometer skala suatu perusahaan. Menurut Apriani \& Rahmanto (2017) perusahaan skala besar lebih mampu menerbitkan laporan keuangannya dengan tepat waktu karena pemegang saham dan pengawas permodalan dalam perusahaan biasanya memonitori secara ketat penerbitan laporan keuangannya. Selain itu, perusahaan besar harus menjaga nama baik atau image baiknya dengan tepat waktunya pelaporan keuangan.

Komite audit adalah orang - orang yang bertanggung jawab dalam membantu menjalankan tugas, fungsi dan wewenang dari Dewan Komisaris. Jika anggota komite audit dalam menjalankan tugas semakin banyak, maka kemungkinan terjadi Audit Delay semakin sedikit. Jika komite audit bertanggung jawab dalam menjalankan tugasnya maka penyimpangan yang akan berkurang, sehingga mempercepat waktu auditor eksternal dalam melaksanakan audit.

$\mathrm{H}_{1} \quad$ : Audit Delay dipengaruhi oleh Ukuran Perusahaan.

Menurut Mumpuni (2011) dalam (Lestari et al., 2017) menyatakan semakin banyak komite audit maka kecil probabilitas terjadi Audit Delay. Dalam perusahaan komite audit bertugas dalam menjalankan fungsi pengawasan, perencanaan, pelaksanaan dan pengendalian internal khususnya dalam proses penyusunan laporan keuangan. (N. K. Sari, 2017) dalam penelitiannya juga menyatakan bahwa adanya komite audit pada suatu perusahaan yang menjalankan pengawasan internal, proses penyusunan laporan keuangan semakin terkendali dan sesuai dengan standar akuntansi yang berlaku umum yang mengakibatkan pemeriksaan laporan keuangan oleh audit eksternal lebih singkat dan berdampak untuk mempersingkat Audit Delay.

$\mathrm{H}_{2}$ : Audit Delay dipengaruhi oleh Komite Audit. 
Opini audit terbagi menjadi 5 jenis yaitu opini wajar tanpa pengecualian, opini wajar dengan pengecualian, opini wajar tanpa pengecualian dengan paragraf penjelasan, opini tidak wajar, opini tidak menyatakan pendapat. Laporan keuangan dengan jenis opini wajar dengan pengecualian biasanya melewati Audit Delay yang lebih panjang, karena auditor harus membahas hasil auditnya dengan senior auditor maupun kliennya. Sementara perusahaan yang hasil audit laporan keuangannya memiliki opini wajar tanpa pengecualian (WTP) Audit Delaynya cenderung lebih singkat dikarenakan hasil auditnya yang baik.

Abadi (2017) menjelaskan bahwa laporan opini auditor merupakan media auditor untuk menyampaikan opini atau pendapatnya sebagai bentuk komunikasi dengan masyarakat lingkungannya. (Aprila et al., 2017) menyatakan bahwa Audit Delay dapat terjadi jika terdapat pengecualian pada opini audit dikarenakan banyaknya faktor yang perlu ditelaah oleh auditor, sebaliknya jika opini tanpa pengecualian kecil probabilitas terjadi Audit Delay.

$\mathrm{H}_{3} \quad$ : Audit Delay dipengaruhi oleh Opini Audit.

Kantor Akuntan Publik dinilai baik dan kompeten apabila mempunyai manajemen audit yang baik, sehingga dalam menjalankan tugas audit, KAP dapat lebih tanggap dalam melakukan pemecahan masalah. Oleh karena itu, penyelesaian audit laporan keuangannya dilakukan lebih singkat dan dapat mengurangi adanya Audit Delay.

Menurut Lucyanda \& Nura'ni (2013), KAP adalah suatu badan usaha yang mempunyai legalitas untuk menjadi tempat bagi akuntan publikmenyalurkan jasanya sesuai dengan regulasi perundang - undangan. Ukuran KAP terbagi menjadi KAP Big Four dan KAP Non Big Four. (E. Puspitasari \& Sari, 2012), kualitas laporan audit dapat menjadi tolak ukur besarnya suatu KAP yang selanjutnya dapat mempengaruhi waktu dalam menyelesaikan laporan. Waktu penyelesaian laporan yang singkat merupakan cara KAP dalam menjaga kredibilitasnya.

$\mathrm{H}_{4} \quad$ : Audit Delay dipengaruhi oleh Ukuran KAP.

Menurut (Prabowo \& Marsono, 2013) menjelaskan bahwa Audit Delay adalah tepat waktunya penyelesaian laporan audit. Pengukuran Audit Delay dihitung berdasarkan jumlah banyaknya hari dalam menyelesaikan laporan auditor dari waktu tutup buku perusahaan. Dengan membandingkan tanggal auditor menandatangani laporan auditor dan tanggal akhir buku perusahaan, maka dapat dihitung jangka waktu penundaan pelaporan laporan audit.

Sebelumnya terjadi kasus pada PT. Garuda Indonesia yaitu terdapat kelalaian akuntan publik dalam mengaudit laporan keuangan perusahaan tersebut. Hal ini disampaikan oleh Kementrian Keuangan yang memaparkan tiga kelalaian audit pada perusahaan tersebut yaitu substansi transaksi untuk perlakuan pendapatan piutang dan pendapatan lain belum dinilai secara tepat oleh akuntan publik yang bersangkutan, penilaian perlakuan akuntansi sesuai dengan substansi perjanjian transakti belum memiliki bukti audit yang cukup kuat dan akuntan publik tidak dapat memberikan pertimbangan berbagai hal atau fakta setelah tanggal pelaporan keuangan sebagai dasar perlakuan akuntansi yang menyebabkan terjadinya Audit Delay pada perusahaan. PT. Garuda Indonesia merupakan salah satu perusahaan transportasi yang sering digunakan oleh masyarakat Indonesia dan ukuran perusahaannya dinilai cukup besar. Dengan 
adanya fenomena kelalaian dalam pengauditan laporan keuangan ini, peneliti tertarik untuk meneliti lebih lanjut mengenai ukuran perusahaan, komite audit, opini audit dan ukuran KAP yang mengaudit perusahaan dalam mempengaruhi Audit Delay. [CNN Indonesia, 28/06/2019]).

$\mathrm{H}_{5} \quad$ : Audit Delay dipengaruhi oleh Ukuran Perusahaan, Komite Audit, Opini Audit dan Ukuran KAP.

Berdasarkan fenomena yang terjadi, peneliti tertarik menarik judul penelitian "Pengaruh Ukuran Perusahaan, Komite Audit, Opini Audit dan Ukuran KAP terhadap Audit Delay pada Perusahaan Transportasi di Indonesia". Berlandaskan penjelasan diatas, kerangka penelitian dapat dituangkan pada kerangka berikut.

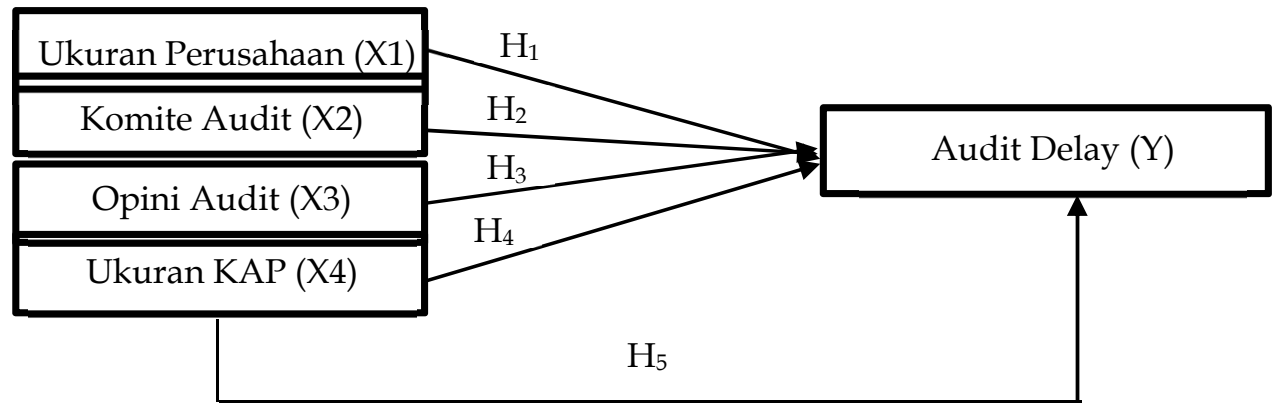

Sumber: Data Penelitian, 2021

Gambar 1. Kerangka Penelitian

\section{METODE PENELITIAN}

Jenis penelitian ini adalah penelitian deskriptif yaitu penelitian yang digunakan dengan tujuan untuk menampilkan gambaran mengenai sejumlah variabel yang berhubungan dengan fenomena yang menjadi dasar penelitian. Peneliti memperoleh data melalui BEI (idx.co.id) dengan populasi sebanyak 46 perusahaan transportasi yang ada di BEI periode 2017-2019. Digunakan teknik purposive sampling dengan kriteria, perusahaan transportasi yang ada di BEI tahun 2017-2019 dan juga yang mengeluarkan laporan keuangan selama 3 tahun. Adapun jumlah perusahaan yang sesuai sebagai berikut.

\section{Tabel 1. Kriteria Sampel}

\begin{tabular}{cll}
\hline No. & \multicolumn{1}{c}{ Kriteria Perusahaan } & $\begin{array}{c}\text { Jumlah } \\
\text { Perusahaan }\end{array}$ \\
\hline 1. & Perusahaan transportasi terdaftar di BEI \\
2. & $\begin{array}{l}\text { Perusahaan yang tidak mengeluarkan laporan keuangan } \\
\text { selama 3 tahun berturut-turut } \\
\text { Total Perusahaan Sampel }\end{array}$ & 46 Perusahaan \\
\hline
\end{tabular}

Sumber: Data Penelitian, 2021

Berdasarkan kriteria yang tertera pada Tabel 1, diperoleh jumlah sampel yang dapat diteliti yaitu 28 Perusahaan $\times 3$ Tahun $=84$ sampel data. Sifat penelitian yang dilakukan menimbulkan hubungan sebab-akibat atau clausa dengan metode penelitian kuantitatif sebagai pendekatan penelitian yaitu dengan penggunaan angka pada variabel penelitian. Adapun Tabel 2, definisi operasional disajikan sebagai berikut. 
Tabel 2. Definisi Operasional

\begin{tabular}{|c|c|c|c|c|}
\hline No & Variabel & Definisi & Indikator & Skala \\
\hline 1 & $\begin{array}{l}\text { Ukuran } \\
\text { Perusahaan }\end{array}$ & $\begin{array}{l}\text { Barometer } \text { banyaknya } \\
\text { jumlah total aktiva } \\
\text { secara keseluruhan } \\
\text { yang } \\
\text { perusahaan miliki. } \\
\text { (Abadi, 2017) }\end{array}$ & $\begin{array}{l}\text { Ln Total aset (K. D. } \\
\text { Puspitasari \& Latrini, } \\
\text { 2014) }\end{array}$ & Rasio \\
\hline 2 & Komite Audit & $\begin{array}{l}\text { Komite } \\
\text { beranggotakan } 3 \text { orang } \\
\text { atau lebih, yang } \\
\text { memiliki r peran } \\
\text { sebagai komisaris } \\
\text { independen sekaligus } \\
\text { ketua komite. (Lestari } \\
\text { et al., 2017) }\end{array}$ & $\begin{array}{l}\text { Jumlah anggota komite } \\
\text { audit (N. K. Sari, 2017) }\end{array}$ & Rasio \\
\hline 3 & Opini Audit & $\begin{array}{l}\text { Auditor memberikan } \\
\text { pendapat yang harus } \\
\text { disertai bukti yang } \\
\text { akurat sebagai } \\
\text { pengambilan } \\
\text { keputusan audit suatu } \\
\text { perusahaan. (Aprila et } \\
\text { al., 2017) }\end{array}$ & $\begin{array}{l}\text { 1. Wajar Tanpa } \\
\text { Pengecualian } \\
\text { 2. Wajar Dengan } \\
\text { Pengecualian } \\
\text { (Nugraha \& Yudowati, } \\
\text { 2018) }\end{array}$ & Dummy \\
\hline 4 & Ukuran KAP & $\begin{array}{l}\text { Semakin baik suatu } \\
\text { KAP akan semakin } \\
\text { berkualitas } \\
\text { auditnya. Uksil } \\
\text { KAP menjadi cermin } \\
\text { besar kecilnya KAP. } \\
\text { (E. Puspitasari \& Sari, } \\
\text { 2012) }\end{array}$ & $\begin{array}{l}\text { 1. Big Four } \\
\text { 2. Non Big Four } \\
\text { (Lucyanda \& Nura'ni, } \\
\text { 2013) }\end{array}$ & Dummy \\
\hline 5 & Audit Delay & 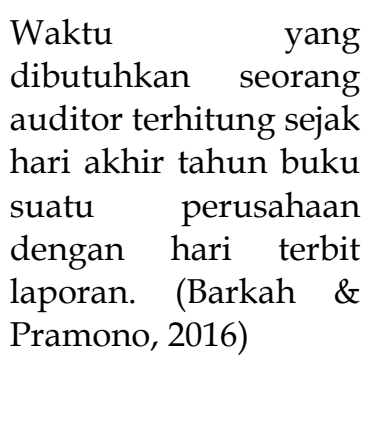 & 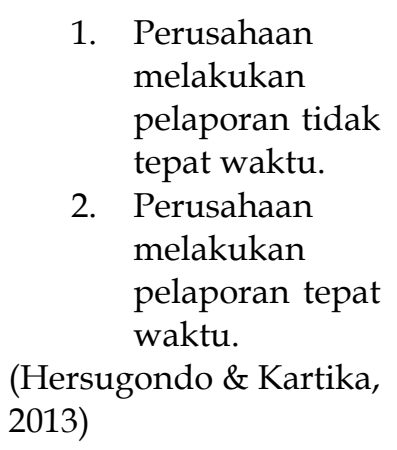 & Dummy \\
\hline
\end{tabular}

Sumber: Data Penelitian, 2021

Pengujian hipotesis dengan metode analisis regresi logistik dikarenakan variabel dependennya merupakan variabel dummy. Model rumus adalah sebagai berikut.

$\operatorname{Lnp} /(1-p)=b 0+b 1 X 1+b 2 X 2+b 3 X 3+b 4 X 4+c$

Keterangan :

$$
\text { Lnp/(1-p) = Audit Delay (1: Audit Delay; 0: Non Delay) }
$$




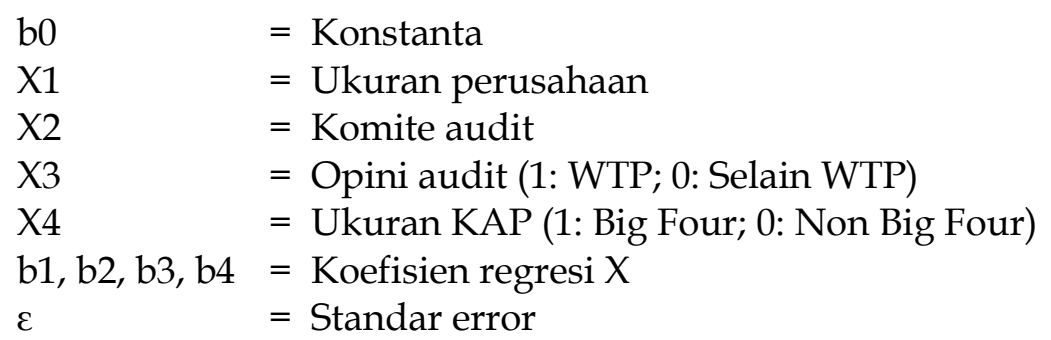

Uji multikolinearitas untuk pengujian hubungan antar variabel bebas pada model regresi. Ghozali (2018:107) dalam (Purnomo \& Aulia, 2019) menjelaskan bahwa pada model regresi seharusnya tak terjadi hubungan antar variabel bebas. Damayanti \& Sudarma (2007) dalam (A. K. Sari et al., 2018)menjelaskan bahwa jika koefisien korelasi $<0.8$, antara variabel independen tidak terdapat gejala multikolinearitas. Hal ini juga dijelaskan oleh (Rahmi \& Fadli, 2017) bahwa apabila $r>0.8$, terdapat korelasi pada variabel bebas yang cukup tinggi atau dengan kata lain terjadi gejala multikolinearitas pada model regresi.

Ghozali (2018:333) dalam (Purnomo \& Aulia, 2019) menjelaskan bahwa statisik -2LL bertujuan untuk mengobservasi pengaruh variabel independen terhadap model fit dengan mengukur selisih -2LL dengan koefisien konstanta dengan -2LL dengan koefisien konstanta dan variabel independen. Jika terdapat penurunan pada -2LL maka model regresi dapat dikatakan baik.

Uji kelayakan model regesi betujuan untuk menguji kecocokan model dengan hasil data yang diobservasi. Ghozali (2013:341) dalam (A. K. Sari et al., 2018) menjelaskan bahwa apabila angka sig. chi-square $>0.05$, maka model regresi dengan hasil data yang diobservasi sama dengan kata lain model regresi mampu memprediksi hasil analisa data.

Uji koefisien determinasi untuk menganalisa kapabilitas variabel independen menjabarkan variabel dependen. Nagelkerke r square berada pada range 0 dan 1. Ghozali, (2011) dalam (Rahmi \& Fadli, 2017) menjelaskan bahwa model dianggap semakin layak apabila angka nagelkerke $r$ square semakin mendekati 1 sebaliknya model diasumsikan kurang layak jika nilainya semakin mendekati 0 .

Matrix klasifikasi tujuannya untuk mengetahui kemampuan model regresi dalam memprediksi probabilitas terjadi Audit Delay pada perusahaan transportasi. Uji G diuji untuk analisa variabel indepeden secara keseluruhan ada pengaruh pada variabel dependen. Uji G dapat diukur melalui uji likelihood dengan kriteria angka sig. chi-square $>0.05$ berarti tiada pengaruh dari variabel independen. Sebaliknya bila angka signifikansi chi-square $<0.05$ berarti ada pengaruh dari variabel independen secara keseluruhan.

Menurut Ghozali (2018:98) dalam (Purnomo \& Aulia, 2019) uji statistik t menjelaskan pengaruh variabel independen secara individu terhadap variabel dependen. Uji $\mathrm{t}$ pada regresi logistik diukur melalui uji wald yaitu membandingkan nilai sig $w$ dengan sig 0.05 , jika nilai sig $w>0.05$ maka variabel independen tidak berpengaruh sebagian, dan jika nilai sig $\mathrm{w}<0.05$ maka variabel independen berpengaruh sebagian. 


\section{HASIL DAN PEMBAHASAN}

Ciri model analisa yang layak untuk diteliti adalah model yang variabel bebasnya tidak ada korelasi antar variable-variabel. Uji multikolinearitas dilakukan untuk melakukan uji pada variabel bebas untuk menemukan benar atau tidak adanya korelasi antar variabel-variabel tersebut. Hasil penelitian disajikan sebagai berikut.

Tabel 3. Correlation Matrix

\begin{tabular}{|c|c|c|c|c|c|c|}
\hline & & Constant & $\begin{array}{c}\text { Ukuran } \\
\text { Perusahaan }\end{array}$ & $\begin{array}{l}\text { Komite } \\
\text { Audit }\end{array}$ & $\begin{array}{l}\text { Opini } \\
\text { Audit }\end{array}$ & $\begin{array}{c}\text { Ukuran } \\
\text { KAP }\end{array}$ \\
\hline \multirow[t]{5}{*}{ Step 1} & Constant & 1,000 & $-0,696$ & $-0,603$ & 0,074 & 0,254 \\
\hline & $\begin{array}{l}\text { Ukuran } \\
\text { Perusahaan }\end{array}$ & $-0,696$ & 1,000 & $-0,148$ & $-0,305$ & $-0,239$ \\
\hline & Komite Audit & $-0,603$ & $-.0,48$ & 1,000 & 0,180 & $-0,132$ \\
\hline & Opini Audit & 0,074 & $-0,305$ & 0,180 & 1,000 & 0,087 \\
\hline & Ukuran KAP & 0,254 & $-0,239$ & $-0,132$ & 0,087 & 1,000 \\
\hline
\end{tabular}

Sumber: Data Penelitian, 2021

Berdasarkan Tabel 3, menunjukkan besaran dari hasil korelasi antar variabel ukuran perusahaan dengan komite audit sebesar 14,8 persen, korelasi antar variabel bebas ukuran perusahaan dengan opini audit sebesar 30,5 persen, korelasi antar variabel bebas ukuran perusahaan dengan ukuran KAP sebesar 23,9 persen. Selanjutnya hasil korelasi antar variabel bebas komite audit dengan opini audit sebesar 18 persen, korelasi antar variabel bebas ukuran KAP sebesar 13,2 persen. Kemudian hasil korelasi antar variabel bebas opini audit dengan ukuran KAP sebesar 8,7 persen. Seluruh variabel berkorelasi dengan nilai korelasi variabel bebas masih berada dibawah 80 persen. Berdasarkan hasil penelitian tersebut, dinyatakan bahwa pada uji multikolinearitas tidak terjadi masalah yang serius antar variabel-variabel yang di uji. Tahapan pertama dalam menggunakan Overall Model Fit, menggunakan pernyataan seperti $\mathrm{H}_{0}$ Ditesiskan sehat sesuai data.dan $\mathrm{H}_{\mathrm{a}}$ Ditesiskan tidak sehat sesuai data.

Tabel 4. Tabel -2 LL Block 0: Beginning Block

\begin{tabular}{lrrrr}
\hline Iteration & -2 Log likelihood & \multicolumn{2}{c}{$\begin{array}{c}\text { Coefficients } \\
\text { Constant }\end{array}$} \\
\hline Step 0 & 1 & 98,702 & & $-0,905$ \\
& 2 & 98,618 & $-0,974$ \\
& 3 & 98,618 & $-0,975$ \\
& 4 & 98,618 & & $-0,975$ \\
\hline
\end{tabular}

Sumber: Data Penelitian, 2021

Berdasarkan fungsi likelihood, statistik -2LL dilakukan dengan menambahkan variabel bebas ke dalam model yang bertujuan untuk mengetahui tingkat signifikansi dalam memperbaiki model fit.

Tabel 5, memperlihatkan nilai - 2LL sebesar 98,618, sedangkan pada Tabel 6, -2LL turun menjadi 78,288. Pada likelihood ini menyatakan dengan adanya variabel X1, X2, X3 dan X4 yang diasumsikan sehat sesuai data yang dianalisa. Pada pengujian Goodness of Fit Test menggunakan nilai sebagai berikut $\mathrm{H}_{0}$ Tidak 
terdapat pengaruh pada data dengan model dan $\mathrm{H}_{\mathrm{a}}$ Terdapat pengaruh pada data dengan model.

Tabel 5. Tabel -2 LL Block 1: Method = Enter

\begin{tabular}{|c|c|c|c|c|c|c|c|}
\hline \multirow{3}{*}{\multicolumn{2}{|c|}{ Iteration }} & \multirow{3}{*}{$\begin{array}{c}-2 \text { Log } \\
\text { likelihood }\end{array}$} & \multicolumn{5}{|c|}{ Coefficients } \\
\hline & & & Conctant & Ukuran & Komite & Opini & Ukuran \\
\hline & & & Constant & Perusahaan & Audit & Audit & KAP \\
\hline \multirow[t]{5}{*}{ Step 1} & 1 & 80,377 & 2,835 & $-0,087$ & $-0,109$ & $-1,597$ & $-0,188$ \\
\hline & 2 & 78,364 & 3,627 & $-.0,98$ & $-0,254$ & $-2,087$ & $-0,308$ \\
\hline & 3 & 78,288 & 3,882 & $-0,097$ & $-0,344$ & $-2,207$ & $-0,339$ \\
\hline & 4 & 78,288 & 3,906 & $-0,097$ & $-0,353$ & $-2,214$ & $-0,340$ \\
\hline & 5 & 78,288 & 3,907 & $-0,097$ & $-0,353$ & $-2,214$ & $-0,340$ \\
\hline
\end{tabular}

Sumber: Data Penelitian, 2021

Berdasarkan cara pengujian Goodness of Fit Test ada ketentuan dalam pengambilan keputusan yaitu Nilai $>0,05$ maka $\mathrm{H}_{0}$ diterima, $\mathrm{H}_{\mathrm{a}}$ di tolak dan Nilai $<0,05$ maka $\mathrm{H}_{0}$ ditolak, $\mathrm{H}_{\mathrm{a}}$ di terima. Apabila nilai yang tersaji lebih tinggi dari 0,05 , artinya model regresi memiliki kemampuan dalam mengobservasi dan memprediksi hasil data yang dianalisa, hal ini menjelaskan bahwa model regresi memiliki kecocokan dengan data yang dianalisa dan dapat diterima.

Tabel 6. Tabel Hosmer and Lemeshow Test

\begin{tabular}{cccccc}
\hline & Step & Chi-square & Df & Sig. & \\
\hline 1 & 3,818 & 8 & & 0,873 \\
\hline
\end{tabular}

Sumber: Data Penelitian, 2021

Dapat dilihat melalui Tabel 6, hasil uji Hosmer E Lemeshow's Test untuk melihat fit atau tidaknya model data yang digunakan. Hal ini ditentukan jika nilai yang ada pada tabel kurang dari ataupun sama dengan 0,05 maka pada uji tersebut terdapat adanya perbedaan antara nilai analisa dengan model yang digunakan. Begitu juga sebaliknya, jika nilainya lebih tinggi dari 0,05 berarti hasil analisa data dapat di perkirakan oleh model. Berdasarkan pada tabel yang tersaji diatas, nilai chi square hitung sebesar 3,818. Kemudian, pada Tabel 3.4 dinyatakan chi square berada di angka df 8 dan memiliki batas signifikansi sebesar 0,05 berarti nilai chi square tabel 15,507. Jadi, dengan angka tersebut dapat dinilai pada nilai chi square hitung yang memiliki nilai sebesar 3,818 lebih kecil dari nilai chi square tabel yang memiliki nilai sebesar 15,507. Dapat diketahui juga pada keterangan tersebut terdapat besaran nilai Hosmer $\mathcal{E}$ Lemeshow's Test pada angka 0,873 yang nilainya lebih tinggi nilai 0,05 . Bersumber pada hasil yang tersaji diatas, dinyatakan data analisa memiliki kecocokan dengan model yang berarti juga tidak adanya terdapat pengaruh yang berarti antara model dibanding data yang ada, juga menyatakan hasil model regresi yang diuji dapat diterima.

Angka Nagelkerke $R$ Square atau perubahan angka Cox \& Snell's harus beragam mulai 0 hingga 1 . Modifikasi ini bisa dilanjutkan dengan membagi antara nilai Cox \& Snell's dengan nilai tertingginya.

\section{Tabel 7. Model Summary}

\begin{tabular}{lrrr}
\hline Step & -2 Log likelihood & \multicolumn{1}{c}{ Cox E Snell R Square } & Nagelkerke R Square \\
\hline 1 & $78,289^{a}$ & 0,215 & 0,311 \\
\hline
\end{tabular}

Sumber: Data Penelitian, 2021

Dapat dilihat dari Tabel 7, disajikan bahwa angka Nagelkerke $R$ Square senilai 0,311 dan nilainya lebih tinggi dari angka Cox \& Snell $R$ Square sebesar 0,215. Dengan angka yang memiliki arti variabel dependen mampu diperjelas dengan 
variabel-variabel bebas yang ada pada Ukuran Perusahaan, Komite Audit, Opini Audit, dan Ukuran KAP sebesar 31,1 persen yang berarti memiliki sisa sebesar 68,9 persen yang diperjelas dari berbagai variabel lainnya yang ada diluar penelitian ini.

Tabel 8. Classification Table

\begin{tabular}{|c|c|c|c|c|c|c|}
\hline & \multirow{3}{*}{\multicolumn{2}{|c|}{ Observed }} & \multicolumn{4}{|c|}{ Predicted } \\
\hline & & & \multicolumn{2}{|c|}{ Audit Delay } & \multirow{2}{*}{\multicolumn{2}{|c|}{ Percentage Correct }} \\
\hline & & & 0,00 & 1,00 & & \\
\hline \multirow[t]{3}{*}{ Step 1} & \multirow{2}{*}{ Audit Delay } & 0,00 & 51 & 10 & & 83,6 \\
\hline & & 1,00 & 9 & 14 & & 60,9 \\
\hline & \multicolumn{2}{|c|}{ Overall Percentage } & & & & 77,4 \\
\hline
\end{tabular}

Sumber: Data Penelitian, 2021

Dapat dilihat Tabel 8 yang tersaji diatas dapat diketahui variabel yang ada mampu memberikan kekuatan untuk mengetahui berapa banyak perusahaan yang mengalami Audit Delay secara keseluruhan sebesar 77,4 persen. Berdasarkan data yang dianalisa, terdapat 23 sampel data yang mengalami Audit Delay dengan persentase 60,9 persen. Sedangkan untuk sampel data yang Non Delay ialah sebanyak 61 sampel data selama periode penelitian dari tahun 2017-2019 dengan persentase sebesar 83,6 persen.

Tabel 9. Tabel Omnibus Tests of Model Coefficients

\begin{tabular}{|c|c|c|c|c|}
\hline \multirow{4}{*}{ Step 1} & & Chi-square & Df & Sig. \\
\hline & Step & 20,330 & 4 & 0,000 \\
\hline & Block & 20,330 & 4 & 0,000 \\
\hline & Model & 20,330 & 4 & 0,000 \\
\hline
\end{tabular}

Sumber: Data Penelitian, 2021

Berdasarkan Tabel 9, nilai chi square adalah 20,330 dan sig. sebesar 0,000< 0,05. Pada kejadian ini menjelaskan H5 diterima yaitu adanya pengaruh pada variabel secara keseluruhan dengan Audit Delay.

Uji parsial bertujuan untuk menganalisa berpengaruh atau tidaknya suatu variabel independen secara individual untuk memberikan keterangan pada variasi variabel dependen atau variabel terikat. Pada uji regresi logistik nilainya dapat dilihat melalui hasil uji statistik wald.

Tabel 10. Variables in the Equation

\begin{tabular}{llllrrc}
\hline & \multirow{2}{*}{ B } & S.E. & Wald & Df & Sig \\
\hline Step 1 ${ }^{\mathrm{a}}$ & & & & & & \\
& Ukuran Perusahaan & -0.097 & 0.149 & 0,424 & 1 & 0,515 \\
& Komite Audit & -0.353 & 1.195 & 0,087 & 1 & 0,768 \\
Opini Audit & -2.214 & 0,624 & 12,604 & 1 & 0,000 \\
& Ukuran KAP & -0.340 & 0,677 & 0,253 & 1 & 0,615 \\
Constant & 3.903 & 4,967 & 0,618 & 1 & 0,432
\end{tabular}

a. Variable(s) entered on step 1: Ukuran Perusahaan, Komite Audit, Opini

Audit, Ukuran KAP.

Sumber: Data Penelitian, 2021

Lnp $/(1-p)=3.903-0.097$ Ukuran Perusahaan-0.353 Komite Audit-2.214 Opini Audit-0.340 Ukuran KAP.

Sig. Ukuran Perusahaan senilai 0,515 yang hasilnya lebih tinggi dari ketetapan 0,05 maka $\mathrm{H}_{1}$ ditolak artinya tidak ada pengaruh pada Audit Delay. Penelitian ini berbanding lurus sesuai penyelidikan oleh (Barkah \& Pramono, 
2016) yang menjelaskan tidak terdapat pengaruh Ukuran Perusahaan terhadap Audit Delay karena baik besar ataupun kecil perusahaan menerima tekanan dalam penyelesaian laporan keuangan karena diawasi oleh pihak pengguna laporan keuangan dan proses audit dilakukan sama terhadap setiap perusahaan. Baik perusahaan besar ataupun kecil, hal ini tidak mempengaruhi Audit Delay karena prosedur audit dan penyelesaian laporan audit yang dilakukan oleh kantor akuntan publik sama untuk setiap perusahaan sesuai dengan standar auditor.

Sig. Komite Audit senilai 0,768 yang hasilnya lebih tinggi dari ketetapan 0,05 sehingga $\mathrm{H}_{2}$ ditolak berarti tidak adanya pengaruh pada Audit Delay. Ini berbanding lurus sesuai penyelidikan oleh (Munthe et al., 2017) menyimpulkan bahwa tidak adanya dampak yang berarti terhadap Audit Delay pada variabel Komite Audit. Ningsih \& Widhiyani (2015) dalam jurnal (Munthe et al., 2017) menjelaskan bahwa komite audit tidak secara aktif menyusun laporan audit karena tugasnya hanya mengawasi susunan laporan, sehingga tertundanya penerbitan laporan kuangan audit yang dapat menyebabkan Audit Delay tidak dipengaruhi oleh komite audit. Berdasarkan penelitian, disimpulkan jika banyaknya anggota tidak memberikan pengaruh pada Audit Delay pada variabel Komite Audit. Berapapun jumlah anggota tidak menentukan penyelesaian laporan audit yang tepat waktu karena tugas Komite Audit hanya sebagai pengawas yang melakukan pengendalian internal dalam penyelesaian berbagai masalah yang ada.

Sig. Opini Audit mempunyai senilai 0,000 dan lebih sedikit dari sig. 0,05 sehingga $\mathrm{H}_{3}$ diterima berarti ada pengaruh terhadap Audit Delay. Penelitian ini berbanding lurus sesuai penyelidikan oleh (Aprila et al., 2017) menjelaskan bahwa apabila opini audit diperoleh auditor semakin baik maka akan mengurangi terjadinya Audit Delay, karena dengan adanya opini positif dari auditor dapat mempercepat perusahaan untuk mempublish laporan keuangannya. Berdasarkan penelitian ini, disimpulkan Opini Audit terdapat pengaruh pada Audit Delay disebabkan adanya keterlambatan auditor dalam menuangkan Opini pada laporan keuangan dapat membuat keterlambatan yang mengakibatkan terlambatnya pelaporan laporan keuangan. Jika pendapat auditor yang diperoleh ialah pendapat yang baik yaitu opini wajar tanpa pengecualian, maka ini termasuk dalam bagian positif dan memberikan efek baik untuk laporan keuangan perusahaan dimana jika opini auditor yang baik diberikan secara tepat dan cepat maka perusahaan dapat mengurangi resiko terjadinya Audit Delay.

Sig. Ukuran KAP senilai 0,615 lebih tinggi dari ketetapan 0,05 maka $\mathrm{H}_{4}$ ditolak berarti tidak terdapat pengaruh terhadap Audit Delay. Hal tersebut berbanding lurus sesuai penyelidikan oleh (Apriyana \& Rahmawati, 2017) menjelaskan jika tidak terjadinya pengaruh pada Audit Delay pada variabel Ukuran KAP karena kualitas KAP tidak menjamin tepat waktunya penyampaian berbagai laporan audit. Tidak terjadi pengaruh pada Audit Delay yang diakibatkan oleh Ukuran KAP karena baik KAP Big Four atau Non Big Four tidak dapat memberikan suatu jaminan bahwa penyelesaian laporan audit dapat dilakukan tepat waktu. Kinerja pada tiap KAP dalam melakukan penyelesaian laporan audit yang memberikan jaminan secara cepat dan tepat yang perusahaan butuhkan agar tidak terjadi keterlambatan audit. 


\section{SIMPULAN}

Berlandaskan dari hasil penelitian diatas kesimpulannya secara parsial variabel Ukuran Perusahaan, Komite Audit, Ukuran KAP tidak mempengaruhi Audit Delay sementara variabel Opini Audit mempengaruhi Audit Delay. Secara keseluruhan Ukuran Perusahaan, Komite Audit, Opini Audit dan Ukuran KAP memberikan pengaruh pada Audit Delay.

Saran kami berdasarkan penelitian yang dilakukan sebagai berikut bagi perusahaan transportasi, perusahaan perlu untuk lebih memperhatikan opini auditor, jika opini audit diberikan terlalu lama maka dapat mempengaruhi keterlambatan penerbitan laporan keuangan. Hal ini yang membuat terjadinya Audit Delay dalam suatu perusahaan. Untuk itu, perusahaan harus memperhatikan opini audit dengan lebih teliti untuk menghindari Audit Delay. Untuk peneliti berikutnya dianjurkan agar menggunakan variabel diluar variabel penelitian ini seperti Kualitas Audit dalam penelitian berikutnya. Selain itu, peneliti selanjutnya dapat memperpanjang jangka waktu atau periode pengamatan, dan juga sangat dianjurkan untuk menggunakan data sampel perusahaan yang berbeda dari penelitian ini misalnya data sampel perusahaan property/real estate.

\section{REFERENSI}

Abadi, G. M. W. (2017). Pengaruh Ukuran Perusahaan dan Opini Audit Terhadap Audit Delay (Studi Empiris pada Emiten Sub Sektor Batubara yang Terdaftar di Bursa Efek Indonesia pada Tahun 2011-2015). E-Proceeding of Management, 4(1), 564-571.

Apriani, S., \& Rahmanto, B. T. (2017). Analisis Pengaruh Profitabilitas, Ukuran Perusahaan Dan Ukuran Kantor Akuntan Publik (Kap) Terhadap Audit Delay Pada Perusahaan Pertambangan Periode 2010 - 2014. Jurnal Riset Manajemen Dan Bisnis (JRMB) Fakultas Ekonomi UNIAT, 2(September), 261-270.

http://jrmb.ejournalfeuniat.net/index.php/JRMB/article/view/59

Aprila, N., Fachruzzaman, F., \& Pratiwi, D. S. (2017). Pengaruh Opini Audit Dan Kualitas Auditor Terhadap Audit Delay Pada Pemerintah Kabupaten/Kota Di Indonesia. Jurnal Akuntansi, 7(3), 75-86.

Apriyana, N., \& Rahmawati, D. (2017). Pengaruh Profitabilitas, Solvabilitas, Ukuran Perusahaan, Dan Ukuran Kap Terhadap Audit Delay Pada Perusahaan Properti Dan Real Estate Yang Terdaftar Di Bursa Efek Indonesia Periode 2013-2015. Nominal, Barometer Riset Akuntansi Dan Manajemen, $6(2)$. https://journal.uny.ac.id/index.php/nominal/article/view/16653

Barkah, G., \& Pramono, H. (2016). Pengaruh ukuran perusahaan, profitabilitas, dan solvabilitas terhadap Audit Delay pada perusahaan manufaktur yang terdaftar di BEI periode 2010-2012. Kompartemen, XIV(1), 75-89.

Hersugondo, \& Kartika, A. (2013). Prediksi Probabilitas Audit Delay Dan Faktor Determinannya. Jurnal Ekonomi Manajemen Akuntansi, 20(35), 1-21.

Lestari, C. S., Rasyidi, A., \& Susanti, W. (2017). Pengaruh Reputasi KAP , Opini Audit dan Komite Audit Terhadap Audit Delay Pada Perusahaan Perbankan 
yang Terdaftar Di Bursa Efek Indonesia Tahun 2013-2015. Jurnal Ekonomi Akuntansi, 3(3), 389-403.

Lucyanda, J., \& Nura'ni, S. P. (2013). Pengujian Faktor-Faktor yang Mempengaruhi Audit Delay. Jurnal Akuntansi Dan Auditing, 9(2), 128-149.

Munthe, I. L. S., Husna, H. A., \& Sepliyani. (2017). Pengaruh Komite Audit, Karakteristik Perusahaan dan Kualitas Auditor Terhadap Audit Delay Pada Perusahaan Manufaktur Yang Terdaftar di Bursa Efek Indonesia Tahun 2012-2015. Universitas Maritim Raja Ali Haji.

Nugraha, I. D., \& Yudowati, S. P. (2018). Pengaruh profitabilitas, opini audit dan kualitas audit terhadap Audit Delay (Studi empiris pada emiten sektor property real estate dan konstruksi bangunan yang terdaftar di Bursa Efek Indonesia pada tahun 2012-2016). E-Proceeding of Management, 5(3), 35983605.

Prabowo, P. P. T., \& Marsono. (2013). Faktor-Faktor Yang Mempengaruhi Audit Delay. Media Riset Akuntansi, Auditing Dan Informasi, 2(1), 1. http:/ / ejournal-s1.undip.ac.id/index.php/accounting persen0AVolume

Purnomo, L. I., \& Aulia, J. (2019). Pengaruh Fee Audit, Audit Tenure, Rotasi Audit Dan Reputasi Auditor Terhadap Kualitas Audit. Analisis Faktor-Faktor Yang Mempengaruhi Thin Capitalization Pada Perusahaan Multinasional Di Indonesia, 1(1).

Puspitasari, E., \& Sari, A. (2012). Pengaruh Karakteristik Perusahaan Terhadap Lamanya Waktu Penyelesaian Audit (Audit Delay) Pada Perusahaan Manufaktur Yang Terdaftar Di Bursa Efek Elen Puspitasari Anggraeni Nurmala Sari Universitas Stikubank Semarang. Jurnal Akuntansi \& Auditing, 9(1), 31-42.

Puspitasari, K. D., \& Latrini, M. Y. (2014). Pengaruh Ukuran Perusahaan, Anak Perusahaan, Leverage dan Ukuran KAP terhadap Audit Delay. E-Jurnal Akuntansi Universitas Udayana, 8(2). https://ojs.unud.ac.id/index.php/Akuntansi/article/view/8145

Rahmi, H., \& Fadli. (2017). Faktor-Faktor Yang Mempengaruhi Pengambilan Keputusan Petani Terhadap Penggunaan Benih Padi Di Kecamatan Nisam Kabupaten Aceh Utara. Agrifo : Jurnal Agribisnis Universitas Malikussaleh, 2(2), 18.

Sari, A. K., Deviyanti, D. R., \& Kusumawardani, A. (2018). Faktor-faktor yang mempengaruhi voluntary auditor switching pada perusahaan yang terdaftar di bei periode 2010-2015. Akuntabel, 15(1), 17-28.

Sari, N. K. (2017). Pengaruh Komite Audit, Ukuran Perusahaan, Kepemilikan Publik, Sistem Pengendalian Internal Dan Penerapan International Financial Reporting Standards (IFRS) Terhadap Audit Delay. Skripsi Mahasiswa Akuntansi IAIN Surakarta. 